\title{
Can labour market institutions explain high unemployment rates in the new EU member states?
}

\author{
Sjef Ederveen $\cdot$ Laura Thissen
}

\begin{abstract}
This article studies the question whether labour market institutions can explain the large differences in unemployment rates in the new member states. It investigates several labour market institutions and concludes that they are on average no more rigid in the new member states than in the old ones. However, there is a lot of heterogeneity both in terms of institutions and unemployment rates. The impact of labour market institutions on performance is empirically examined for a panel of European countries. These results are used to assess to what extent labour market institutions are responsible for the diverse unemployment experiences in the new member states. Labour market institutions can explain only a small part of these differences. Other causes of unemployment seem to be more important.
\end{abstract}

Keywords Labour market institutions - Unemployment - Transition economies · EU accession countries

JEL codes $\mathrm{E} 24 \cdot \mathrm{H} 2 \cdot \mathrm{J} 5 \cdot \mathrm{J} 64 \cdot \mathrm{J} 68 \cdot \mathrm{P} 2$

\begin{abstract}
This research was conducted while both authors were affiliated at the CPB Netherlands Bureau for Economic Policy Analysis. Financial support under the European Commissions 5th Framework programme in the ACCESSLAB project is gratefully acknowledged. The authors benefited from discussions during the ACCESSLAB workshops and comments by Michèle Belot, Albert van der Horst, Arjan Lejour, Michiel van Leuvensteijn, Ruud de Mooij and Paul Tang. The views expressed in this paper are the views of the authors and do not necessarily reflect the views of the Dutch Ministry of Economic Affairs.
\end{abstract}

S. Ederveen $(\bowtie)$

Dutch Ministry of Economic Affairs, P.O. Box 20101, 2500 EC The Hague, The Netherlands e-mail: s.ederveen@minez.nl

L. Thissen

ECORYS Nederland BV, P.O. Box 4175, 3006 AD Rotterdam, The Netherlands

e-mail: laura.thissen@ecorys.nl 


\section{Introduction}

In May 2004, eight Central or East European countries and two Southern European islands joined the 15 members of the European Union (EU-15). ${ }^{1}$ Under the centrally planned systems in most of these countries, the labour market institutions were rigid: employees enjoyed a high degree of employment protection legislation and pay systems were fairly rigid (Nesporova 2002). One month before the accession the European Commission (EC) published her recommendations on the update of the Broad Guidelines of the Economic Policies of the Member States and the Community for 2003-2005. In the recommendations per country, the EC made remarkably little distinction between countries with high and with low unemployment, even though differences are large: Hungary had an unemployment rate of $6 \%$ in 2004, whereas unemployment in Poland reached almost 20\%. The Commission advised the new member states to lower their tax wedge, remove disincentives in the benefit system, and increase spending on active labour market policies, in other words: reform their labour market institutions in order to address the poor labour market performance.

The Commission's advice is consistent with the general economic view, mainly based on research for OECD-countries, which suggests that labour market institutions determine the rigidity of a labour market. Since flexible labour markets are better equipped to respond to changes in labour supply and demand, unemployment rates are lower in countries with flexible labour markets. Unemployment in the new member states is perceived to be high. Combining this with their history of rigid labour markets, it is reasonable to expect that a similar relationship between rigid labour markets and poor labour market performance holds for the new member states as well. If so, a solution is easily found: the new member states with high unemployment rates need to reform their labour market institutions in order to lower unemployment.

This article aims at answering the question whether labour market institutions can indeed explain the large differences in unemployment rates in the new member states. The paper is focussed around two central research questions. First, do labour market institutions between the new member states and the old member states indeed differ widely? And second, to what extent can differences in labour market outcomes be explained by differences in institutions alone?

The next section starts by comparing the average labour market institutions in the new member states with those in the EU-15. The comparison with the EU-15 is especially relevant, as a number of new member states will probably enter the European Monetary Union in the near future. However, it is often argued that the labour markets in the new member states are too rigid to sufficiently absorb asymmetric shocks. But are they really more rigid? After transition to a market economy set in post-Communist countries, the social security system has been revised drastically, labour market regulation has been moderated, and all countries have moved away from the centralised bargaining system. After all these reforms,

\footnotetext{
${ }^{1}$ In this article, the 15 pre-2004 members of the European Union are referred to as EU-15, whereas the ten countries that joined the Union in May 2004 are referred to as 'new member states' or NMS-10.
} 
where do the new member states position themselves in the rigidity ranking now? Section 2 takes up this issue. It describes labour market institutions in the new member states, assesses the rigidity of their labour markets and compares them with the EU-15. The main conclusion is that on average labour market institutions are no more rigid in the new member states than in the old ones.

Even if labour market institutions are in general no more rigid in the new member states than in the EU-15, differences in institutions may still explain the huge variation in labour market outcomes. Section 3 explores this issue econometrically. It empirically examines the impact of labour market institutions on labour market performance in a panel of European countries. These results are used to assess to what extent labour market institutions are responsible for unemployment in the new member states. Only a minor part of these differences can be explained in this way. Section 4 winds up the article. It summarizes our findings and discusses a number of other factors, like postponed structural reforms, which may have caused unemployment in the new member states. The article concludes with some policy conclusions.

\section{Rigidity of labour market institutions in the new EU member states}

By now it has been well established that high unemployment can be caused by rigid labour market institutions such as generous unemployment insurance schemes, high unemployment protection, severe tax distortions and non-competitive wage-setting mechanisms (e.g., Nickell et al. 2003; IMF 2003). The observation that unemployment is extremely high in some of the new member states with a history as centrally planned economies, especially in Poland and Slovakia, may easily lead one to conclude that it is inflexible labour market institutions that are to blame in these countries.

However, is this really true? This section assesses the usual suspects causing labour market rigidities (see e.g., Nickell et al. 2005): replacement rates, tax wedges, wage bargaining, and employment protection legislation. ${ }^{2}$ The performance on these labour market institutions in the new member states will be presented relative to those in the EU-15. In this way, it can be determined whether labour market institutions can explain different behaviour in both groups.

\subsection{Replacement rates}

It almost goes without saying that higher unemployment benefits may increase unemployment. The reason is that higher benefits raise the fallback position of the worker, that is the expected income if negotiations break down. Most countries that have just joined the EU share a history as centrally planned economies. At the outset of transition to a market economy, there was no unemployment in these countries.

\footnotetext{
${ }^{2}$ A more comprehensive overview can be found in Sjef Ederveen and Laura Thissen: 'Can Labour Market Institutions explain high unemployment rates in the new EU member states?', CPB Document 59, April 2004.
} 
Most of the new East-European governments introduced fairly generous unemployment benefits (both in terms of eligibility, levels and duration). However, in the beginning of the 1990s unemployment rose sharply and so did the claims on benefits. Many countries reacted after 1991 by making eligibility rules more restrictive, shortening the duration of entitlement and cutting unemployment benefits (Scarpetta and Reutersward 1994). This resulted in a significant decline of the replacement rates, i.e., the level of benefits relative to the wage level.

The OECD provides gross replacement rates for the Visegrad countries Poland, Hungary, Czech Republic and Slovakia. Table 1 gives these for the first 5 years of unemployment. For the first year of unemployment the average replacement rate in the new member states is comparable to those in for instance Greece and Ireland and higher than in the United Kingdom. The striking fact is that in all of these four new member states unemployed do not receive any benefits in the subsequent years of unemployment. In comparison, average replacement rates in the EU-15 in the 2nd3 rd, and 4th-5th year of unemployment are $32 \%$ and $15 \%$, respectively. It can be concluded that replacement rates are much lower in the new member states and that it is rather unlikely that unemployment benefits per se would discourage benefit recipients from taking up a job.

\subsection{Tax wedge}

In addition to the social security benefits system, taxes also play a role in the redistribution of income. Intuitively, a higher tax wedge raises the relative attractiveness of working in the informal sector. These activities are not taxed because they simply are not subject to taxation, for instance household production, or because taxes are evaded (black market activities). Moreover, a high wedge promotes inflexibility since it can be detrimental to job creation.

Table 2 shows the tax wedge, defined as employees' and employers' social security contributions and personal income tax less transfer payments as a percentage of gross labour costs. Although high taxes on labour are often perceived as one of the causes for high unemployment in for instance Poland (EC 2004), Table 2 clearly shows the tax wedge in the new member states is not significantly

Table 1 Average gross replacement rates over a 5-year period, 2001

\begin{tabular}{llll}
\hline & First year & Second and third years & Fourth and fifth years \\
\hline $\begin{array}{l}\text { New member states } \\
\text { (mean for 4 countries) }\end{array}$ & 31.5 & 0 & 0 \\
EU-15 Mean & 53.8 & 31.7 & 14.7 \\
US & 29 & 5.7 & 5.7 \\
\hline
\end{tabular}

Source: OECD (2004, p. 104)

Gross replacement rates are averaged over three family categories (single, with dependent spouse, with spouse in work) and two income levels (2/3 and 100\% of the Average Production Worker earnings level) Mean for the new member states is calculated for Poland, Hungary, Czech Republic and Slovak Republic 
Table 2 Tax wedge, 1999

\begin{tabular}{llll}
\hline Poland & 42.9 & Estonia & 40.0 \\
Hungary & 52.6 & Lithuania & 39.7 \\
Czech Republic & 43.0 & Latvia & 41.7 \\
Slovak Republic & 42.0 & Cyprus & 16.5 \\
Slovenia & 41.0 & Malta & 16.4 \\
EU-15 min (Ireland) & 25.8 & & \\
EU-15 max (Belgium) & 55.6 & & \\
EU-15 weighted average & 43.2 & & \\
\hline
\end{tabular}

Source: OECD (PL, HU, CZ, SK and EU-15)/Eurostat (other countries, for low-earners). Tax wedge is employees' and employers' social security contributions and personal income tax less transfer payments as percentage of gross labour costs

higher than the average wedge in the EU-15. Hungary is the only country with a tax wedge above the EU-15 average.

\subsection{Collective wage bargaining: union density, coverage, and coordination}

An important determinant of the outcome of the wage bargaining process is the relative bargaining power of the employee or trade union relative to the employer('s association). The bargaining position depends primarily on the number of people that unions represent. The higher union density is, the better is the relative bargaining position of the trade unions.

In most EU-15 countries, unions still play a major role in the process of wage bargaining. Union density may be low in some countries (Germany, France, Spain), union coverage (i.e., the number of workers, unionised or not, who have their pay and working conditions determined by collective agreements in the enterprise sector) remains high. Collective agreements cover over $70 \%$ of the labour force in all countries except the UK, and reach well over covering $90 \%$ in some countries (Finland, Germany, France, and Austria).

The new member states give a more homogeneous picture (Table 3). Also in these countries density has declined, but more importantly for bargaining power, union coverage is about the same as in the EU-15. In Slovenia, membership of the bargaining organisation is compulsory, implying complete coverage (EC 2003). Significant differences have emerged between the public and the private sectors, with much lower unionisation in the latter. Workers in medium-sized and small firms are rarely unionised (Nesporova 2002). Although coverage is about as high as in the EU-15, bargaining power of the union depends heavily on coordination ability which is actually rather low in most of the new member states (World Bank 2002).

The institutional level at which negotiations take place is another factor that influences the outcome of the bargaining process. Three levels of wage bargaining can be distinguished: firm- or plant-level (decentralised bargaining), industry-level (bargaining at the intermediate level) and countrywide level (centralised bargaining). In many countries, also informal networks and intensive contacts between social partners coordinate the behaviour of trade unions and employers' associations. Examples are the leading role of a limited number of key wage settlements in Germany, and the active role of powerful employer networks in Japan (Soskice 
Table 3 Union bargaining power: density, coverage, and coordination

\begin{tabular}{llll}
\hline & Density & Coverage & Coordination \\
\hline Poland & 34 & $70-100$ & 1.5 \\
Hungary & 60 & $70-100$ & 1.5 \\
Czech Republic & 43 & $26-69$ & 1 \\
Slovak Republic & 62 & $70-100$ & 2 \\
Slovenia & 60 & $70-100$ & 3 \\
Estonia & 36 & $26-69$ & 1.5 \\
Sweden $^{\text {a }}$ & 91 & 89 & 2 \\
Germany $_{\text {France }}$ & 26 & 92 & 3 \\
Italy & 10 & 95 & 2 \\
United Kingdom & 39 & 82 & 3 \\
United States & 34 & 47 & 1 \\
\hline
\end{tabular}

Source : EU member states: OECD (1997, 1994); New member states: Cazes (2002) \& Riboud (2002), late 1990 s

Coordination is given in indices ranging from 1 (low coordination) to 3 (high coordination)

${ }^{\text {a }}$ Until 1995, a national law stated compulsory membership of a trade union in Sweden

1990). Therefore, not only the formal degree of centralisation matters, but also the degree of informal consensus seeking between bargaining partners. This is generally called the level of coordination. For highly centralised bargaining systems, the degree of coordination and centralisation are likely to coincide. More decentralised systems may, however, exhibit higher degrees of coordination than the formal level of centralisation suggests. This can be observed within the EU-15: during the past years, a decentralising trend towards bargaining at the industry level has taken place whilst coordination remains to be on a high level, and has even been increasing (except in Sweden and the UK).

Before the transition commenced, the state controlled the wage bargaining process in the Central and East European countries. Wages did not reflect productivity or performance. After transition, all Central- and East-European countries started to move away from the centralised bargaining system and efforts were made to develop a collective bargaining system at the firm level. In practice, although basic guidelines are sometimes established through tripartite negotiations with the government, most wage bargaining takes place at the industry or the firm level, and in the private sector employers set wages. Nowadays the wage bargaining process in the new member states is more decentralized than in the EU- 15 .

\subsection{Employment protection legislation}

Finally, the degree of employment protection legislation (EPL) in the new member states and the EU-15 will be compared. Before transition, employees in the centrally planned economies of the new member states enjoyed a fairly high degree of employment protection. Over the 1990's, the need for rapid structural adjustment of 
the transition economies after the introduction of economic and social reforms resulted in substantial moderation of EPL, partly enabled by weakening of trade union power. The objective was to facilitate workforce adjustment for firms in order to make enterprises more flexible and competitive. During the 1990's, legislation on employment protection has been revised several times, resulting in re-tightening of employment protection in some countries and its further moderation in others (Cazes 2002).

Strict dismissal protection rigidifies the labour market in the sense that it becomes more difficult and more expensive for businesses to lay off staff. Dismissal protection is therefore attractive for those who have a job, but unfavourable for job seekers. This will tend to reduce short term unemployment and raise long term unemployment. The ultimate effect on total unemployment is however ambiguous (Mortensen and Pissarides 1999).

Figure 1 shows EPL concerning regular employment, temporary employment and collective dismissals. It turns out in particular collective dismissals are difficult to achieve in the new member states. With respect to regular employment, Hungary and Poland enforce the least strict laws. In Hungary, a written statement to the employee suffices for dismissal. In both countries, job redundancy or unsatisfactory performance suffices for dismissal, the notice period is short and the severance pay small. The Czech Republic and Hungary have least employment protection regarding temporary employment (renewal and maximum duration of contract). Hungary does have high employment protection when collective dismissals are

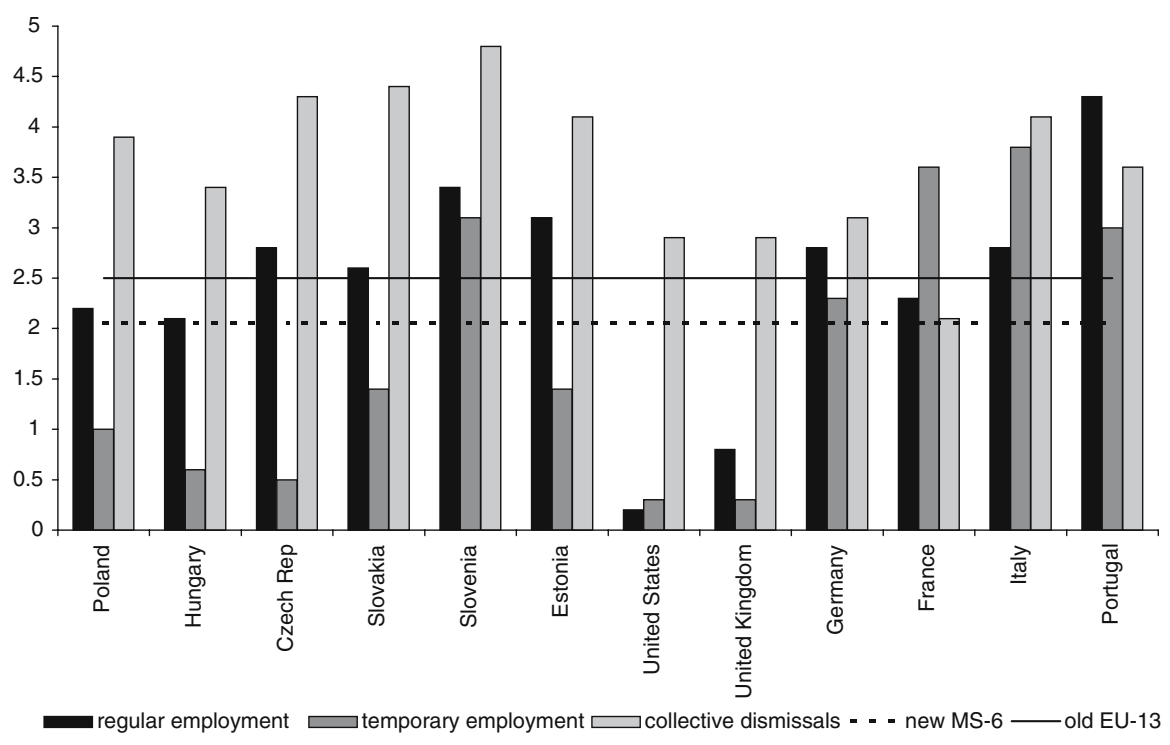

Fig. 1 Strictness of employment protection legislation on scale 0-6 (most strict), late 1990's Source: World Bank (2002) \& Riboud (2002). Employment protection legislation is given for three categories: legislation concerning regular employment, temporary employment, and collective dismissals 
concerned; in Slovenia employees are least protected when large groups of people are fired at the same time (Riboud et al. 2002; Nesporova and Cazes 2003).

In comparison, on average, employment protection legislation is not stricter in the new EU member states than in the EU-15. On the one hand, labour markets known to be flexible (UK, US, Ireland) have less strict employment protection than the new member states. ${ }^{3}$ Hungary has least restrictive laws, but still considerably stricter than in the US. On the other hand, Southern European countries have the most strict employment protection laws, protecting their employees at about the same level as in Slovenia, the country scoring highest among the new member states shown.

\subsection{Conclusion: rigidity ranking}

Much has happened in the new member states in the past decade. Since the beginning of the transition, the social security system has been revised drastically: replacement rates are now comparable to those within the old EU-15, but benefit duration is markedly shorter in the new member states. Employment protection was liberalised and minimum wages were introduced. The collective agreements, as bargained over at the decentralised industry or firm level, now cover the majority of employees in the new member states. In short, labour market institutions in the new member states do on average not differ that much anymore from the institutions in the old member states. If anything, they should be considered more flexible:

- Replacement rates are lower and duration is shorter: after 1 year of unemployment no unemployment benefit is issued anymore in most new member states.

- In the wage-setting process, coordination is lower in the new member states. In general, bargaining takes place at the firm level.

- Employment protection legislation is less strict: only collective dismissal legislation is stricter in the new member states than in most old member states.

- Tax wedges are comparable. Only in Hungary it significantly exceeds the average tax wedge in the EU-15.

\section{The quantitative effect of labour market institutions on unemployment}

To what extent does the design of labour market institutions in the new member states provide an explanation for the level of unemployment rates in these countries? From the previous section it is clear that labour market institutions are in general no more rigid in the new member states than in the EU-15. This observation may easily lead one to conclude that the rigidity of the labour market can not possibly be a major determinant of the differences in unemployment between both

\footnotetext{
${ }^{3}$ Boeri (2002) suggests that employment protection is an alternative form of insurance against labour market risks. He shows a trade-off between employment protection (particularly relevant in Mediterranean countries) and social security (mainly relevant in corporatist and social-democratic countries).
} 
groups of countries. However, contrary to common belief, unemployment is on average also not that different between both groups of countries. In fact, about half of the new member states feature unemployment rates below the EU-15 average. To identify the possible impact of labour market institutions on unemployment in the new member states, the focus should therefore be on the labour market performance of the individual countries.

To address this question this section analyses the effects of labour market institutions on unemployment empirically in a panel of 21 countries. This analysis does not aim at deriving new insights about their impact, but rather it aims at assessing whether accepted elasticities can explain a major part of the variation. The parameter estimates are then used to assess to what extent labour market institutions can explain unemployment rates in the new member states. If labour market institutions are the major determinant of unemployment in the new member states, the regression results should certainly explain a substantial part of the variation.

\subsection{Methodology}

Quantifying the relationship between unemployment and labour market institutions has been the topic of several studies. Two broad lessons can be drawn from the existing body of empirical work: (i) institutions matter and a substantial part of the fluctuation in unemployment can be explained by changes in the institutional structure; (ii) theoretical predictions about the way institutions influence unemployment are confirmed by the econometric results. These empirical studies invariantly use a selection of about 20 highly developed OECD countries. It is not at all sure that the explanatory power of labour market institutions for unemployment is the same for countries in a different phase of development. Our aim is to link up with the existing empirical work to understand whether the lessons about the impact of labour market institutions on unemployment also hold for the new member states.

Econometric analyses of the impact of institutions can be divided in two different types (see e.g., the overview of Nickell et al. 2005). First, there are studies that focus on 'shocks' and their interaction with institutions that are assumed to be constant over time (see e.g., Blanchard and Wolfers 2000). A second type of econometric studies relies on changing institutions to explain unemployment patterns. Here, a subdivision can be made of studies that use averages over institutions for different periods to explain the long-term unemployment trends and studies that use annual data to explain actual unemployment. An example of the latter is provided by Nickell et al. (2003). The other type of studies that relates changing institutions to unemployment is static in the sense that it does not aim at explaining the exact annual level of unemployment, but rather the underlying structural trend. This kind of studies therefore does not rely on the measurement of shocks. Belot and Van Ours (2004) provide a notable example of this line of reasoning.

This study of Belot and Van Ours (2004) is a convenient starting point for our analysis for at least two reasons. First, it assesses the structural impact of the institutional framework on unemployment, rather than the interaction of shocks and institutions or the explanation of actual unemployment. This fits nicely with the objective of this study: it seeks to explore whether unemployment in the new 
member states can be explained by the way labour market institutions are built. Second, it uses data for the period 1960-1999, whereas most other empirical studies use a sample till 1995. Using these recent years in the empirical analysis is essential for the purpose of this study, as unemployment in the new member states only stabilised at around 1995. At that time, markets had adapted somewhat to the new circumstances.

The impact of the labour market institutions on unemployment can be estimated in standard panel data techniques. In this paper, the regressions are estimated for an unbalanced panel of 21 countries. The empirical results are based on 5 year averages; the maximum number of observations is therefore eight 5-years periods (covering the period 1960-1999) times 21 countries $=168$ observations. However, for the four new member states data is only available for the last 5-year period, so the maximum number of observations is reduced to 140 . All the regressions include dummies for the time periods included to account for cyclical variation. Furthermore, the change in inflation is included in the regressions in a modest attempt to control for some of the deviations from the structural unemployment rate.

To be able to assess the impact for the new member states, we had to use different data for a number of labour market institutions compared to Belot and Van Ours (2004). Belot and Van Ours kindly provided us with the data they used. These include the tax wedge, replacement rate, employment protection, union density and centralisation as well as data for unemployment and employment for seventeen OECD-countries. ${ }^{4}$ The sample has been extended with the four largest new member states (Poland, the Czech Republic, Hungary and the Slovak Republic). ${ }^{5}$ In order to include these countries, different indicators for both the tax wedge and for employment protection legislation are used. In addition, series for the replacement rate in the first year and the duration of unemployment benefits, for statutory minimum wages (as percentage of average wages) and for Active Labour Market Policy (normalised on the percent unemployment rate) have been constructed. A detailed description of sources and computations can be found in the Data Appendix at the end of this document.

\subsection{Estimation results}

Table 4 presents the results of our regressions. The first column in Table 4 shows the estimation results of our benchmark specification. ${ }^{6}$ The results imply that the unemployment rate is positively influenced by taxes and by benefit duration. Surprisingly, the first year replacement rate has a negative impact. Stricter employment protection and more coordination also significantly lower unemployment.

\footnotetext{
4 These are Australia, Austria, Belgium, Canada, Denmark, Finland, France, Germany, Ireland, Italy, Japan, the Netherlands, Norway, Sweden, Switzerland, United Kingdom and United States of America.

5 Including other acceding countries severely restricts the number of labour market institutions we could include in the regressions.

6 We have also experimented with interactions between institutions. In contrast to Belot and Van Ours (2004), these interaction terms turned out insignificant in our regressions and we therefore decided not to show these here.
} 
Table 4 Regression results explaining the unemployment rate in 21 countries

\begin{tabular}{llll}
\hline & $(1)$ & $(2)$ & $(3)$ \\
\hline Tax Wedge & $0.142^{* *}$ & $0.194^{* *}$ & 0.039 \\
Replacement Rate first year & $-0.024^{*}$ & 0.011 & $0.074^{* *}$ \\
Benefit Duration & $0.014^{* *}$ & 0.006 & -0.013 \\
Employment Protection Legislation & $-0.027^{* *}$ & -0.017 & -0.000 \\
Union Density & 0.019 & $0.039^{* *}$ & $0.099^{* *}$ \\
Coordination & $-0.012^{* *}$ & $-0.011^{*}$ & $-0.011^{* *}$ \\
Active labour market policies & & $-0.133^{* *}$ & $-0.136^{* *}$ \\
Minimum Wage & & & $0.144^{* *}$ \\
Change in Inflation & $-0.503^{* *}$ & $-0.652^{*}$ & -0.537 \\
Adjusted R2 & 0.57 & 0.48 & 0.63 \\
Total number of observations & 140 & 72 & 44 \\
Period & $1960-1999$ & $1980-1999$ & $1980-1999$ \\
Time dummies? & Yes & Yes & Yes \\
\hline
\end{tabular}

** Indicates $5 \%$ significance-levels, * 10\%. Significance is based on White heteroskedasticity consistent standard errors

Below, the interpretation of the coefficients is discussed in more detail. The tax wedge has a major effect on unemployment: A 1\%-point higher tax wedge raises unemployment by $0.14 \%$. Regarding the unemployment benefit system, instead of using one summary variable, we try to disentangle the effects of the level of benefits and the duration of entitlement. According to our estimations the first-year replacement rate has an unorthodox negative albeit small effect on unemployment, whereas a higher duration of entitlement does significantly increase unemployment. Both variables were expected to exert upward pressure on unemployment, as has been found by Nickell et al. (2003). A possible explanation is that the tax wedge and the replacement rate are correlated. Nickell et al. (2003) do not include the latter variable.

Theory is ambiguous about the effects of employment protection legislation on unemployment. It is often argued that employment protection legislation does change the dynamics of unemployment, but does not significantly affect the level of unemployment (e.g., OECD, 1999). In contrast, our results imply that stricter employment protection significantly lowers unemployment. This supports the findings of Belot and Van Ours (2004), but contradicts the results of some other studies. An implication is that a rigid labour market is not necessarily bad for employment. As the corresponding variable ranges from zero to one, the maximum effect of stricter regulations is $2.7 \%$.

Turning to wage formation, union density and coordination were included as independent variables. The bargaining power of trade unions improves with more members, so higher union density is expected to lead to higher wage demands at the expense of higher unemployment. The estimated coefficient is indeed positive, albeit small and statistically not significant. Coordination of wage bargaining leads to lower unemployment: under fully coordinated bargaining unemployment is $2 \%$ 
lower than under fully uncoordinated bargaining. Our results thus support the corporatist view of wage bargaining. This result is in line with most other empirical studies.

The basic model is extended by including data on active labour market policies and minimum wages. ${ }^{7}$ Data on both variables are only available from the 1980 s onward, so when including these half of the observations had to be dropped. The second column in Table 4 shows the regression results when the analysis of the first column is extended with expenditure on active labour market policies, measured as the amount per unemployed. The regressions are run for the period 1980-1999 and include 72 observations. The results show that active labour market policies significantly affect unemployment: when more money is targeted on unemployed in the form of one of the various programmes covered under the heading active labour market policies, unemployment decreases. This extension does have some effects on the other estimated coefficients. The impact of the replacement rate now turns positive, as expected, although the effect is not significant. The estimated impact of both benefit duration and employment protection also loose significance, but keep the expected sign. In contrast, the estimated impact of union density becomes significant: a $10 \%$ increase in union membership raises unemployment by $0.4 \%$.

Including minimum wages poses some more problems. In a number of countries no statutory minimum wage exists, but industry- or occupation-specific minimums are set by legislation or collective bargaining agreements. It is possible to include the summary estimates constructed by Dolado et al. (1996) for these countries, as has been done in some other empirical studies. This practice is not followed here, because (i) this series has not been updated and (ii) the Dolado-series does not use the same denominator as the OECD-series. In the present study the empirical analysis is restricted to the countries for which statutory minimum wages exist. ${ }^{8}$ The results are presented in the last column of Table 4 and use 44 observations from the period 1980-1999. In line with theoretical predictions, minimum wages (measured as a percentage of median wages) significantly raise unemployment. The estimated coefficient implies that increasing the minimum wage relative to the median wage by $1 \%$, results in $1.4 \%$ more unemployment. This addition has also implications for some of the other estimated coefficients. Most striking is that the tax wedge is no longer significant, but that the estimated effect of the replacement rate becomes highly significant and much larger than in the other regression results. This may be due to the fact that replacement rates and tax wedges are highly correlated. It may therefore be hard to disentangle both effects. The coefficient on union density is also influenced by adding the minimum wage variable to the regression: it becomes much more important than in the earlier results.

\footnotetext{
${ }^{7}$ These were probably the most interesting results of an extensive robustness analysis, in which different countries and different variables were left out, different time periods were used and new variables were added. Although the exact parameter estimates were quite sensitive for some of the variants, the qualitative results were quite robust and what is most important, the conclusions with respect to the explanatory power for the new member states were never altered. The exact results are available upon request.

8 These are Australia, Belgium, Canada, France, Ireland, Japan, the Netherlands, New Zealand, United Kingdom, United States of America, Poland, Hungary, the Czech Republic and the Slovak Republic.
} 
In conclusion, the empirical results seem to provide support for the theoretical predictions on the influence of labour market institutions on unemployment. The effects are however sensitive to the specification of the regression, the sample period used and the countries considered. These results therefore should not be interpreted as exact estimates of the effects of labour market institutions on unemployment, but they provide an idea of the importance of different factors.

\subsection{Implications for unemployment in the new member states}

Since the exact estimation results in the previous section are quite sensitive to the specification of the regression equation, we do not expect to be able to fully explain the differences in unemployment rates. However, the results are in line with theoretical predictions and with other empirical work. So, if labour market institutions are a major determinant of unemployment in the new member states, the regression results should certainly explain a substantial part of the variation.

The first column of Table 5 shows the average unemployment rates over the period 1995-1999 in the four new member states that were included in the regression analysis: the unemployment rate ranges from $7.5 \%$ in the Czech Republic to no less than $14.5 \%$ in the Slovak Republic. The next columns confront these values with the unemployment rates that are implied by the results of the regression in Table 4. The second column shows the results if one applies the estimated coefficients from the first regression (covering 1960-1999 without active labour market policies and minimum wages).

In contrast to reality, the implied unemployment rate turns out to be lowest for the Slovak Republic. There are two reasons for this result: the tax wedge is a bit lower in the Slovak Republic than in the other new member states and wage formation is relatively coordinated. According to the regression results, both aspects have a downward effect on unemployment. The highest implied unemployment rate is found for Hungary. This also seems at odds with the data: the official unemployment figure for Hungary is quite low. However, a more detailed inquiry into the Hungarian figures reveals the modest unemployment rate is accompanied by extremely low employment. The last but one column of Table 5 shows the employment rates for the new member states. Average employment over the period 1995-1999 was only 53\%, lower than in any other country considered. From these data it seems that much hidden unemployment exists in Hungary. The declining unemployment rates in the 1990s were not matched by increasing employment

Table 5 Actual and implied unemployment rates in the new member states

\begin{tabular}{lcccccc}
\hline & $\begin{array}{l}\text { Actual UR } \\
\text { ('95-'99) }\end{array}$ & $\begin{array}{l}\text { Implied } \\
\text { UR (1) }\end{array}$ & $\begin{array}{l}\text { Implied } \\
\text { UR (2) }\end{array}$ & $\begin{array}{l}\text { Implied } \\
\text { UR (3) }\end{array}$ & $\begin{array}{l}\text { Actual ER } \\
\text { ('95-'99) }\end{array}$ & $\begin{array}{l}\text { Actual UR } \\
(2005)\end{array}$ \\
\hline Poland & $11.5 \%$ & $10.7 \%$ & $12.1 \%$ & $11.2 \%$ & $58.4 \%$ & $17.7 \%$ \\
Hungary & $8.5 \%$ & $11.1 \%$ & $13.0 \%$ & $12.4 \%$ & $53.0 \%$ & $7.2 \%$ \\
Czech Republic & $7.5 \%$ & $10.1 \%$ & $11.1 \%$ & $8.0 \%$ & $69.1 \%$ & $7.9 \%$ \\
Slovak Republic & $14.5 \%$ & $8.1 \%$ & $10.3 \%$ & $11.5 \%$ & $59.5 \%$ & $16.3 \%$ \\
\hline
\end{tabular}


levels. Unemployed people do not register anymore since Hungary toughened the unemployment benefit eligibility criteria, or they have found a job in the underground economy. In any case, labour market institutions might be more of a burden than actual unemployment figures seem to suggest. Especially the tax wedge is extremely high at $51.5 \%$. However, this does not change the conclusion from looking at the results for all four countries that labour market institutions are not the main determinant of unemployment in the new member states.

The third column shows the implied results from the second regression, where expenditure on active labour market policies is included. The implied unemployment rates increase in all new member states, reflecting the relatively low spending on active labour market policies. The order between the four new member states does not change: the implication of labour market institutions alone would be that unemployment in the Slovak Republic is lower than in the three other countries.

In the fourth column the results of the final regression (with minimum wages) are used for the computations. This has a major impact on the results. Implied unemployment is now lowest in the Czech Republic, in accordance with reality. The reason behind this result is twofold. First, minimum wages are low in the Czech Republic. Second, in the regression result replacement rates have gained importance at the expense of the tax wedge. Because the replacement rate is very low in the Czech Republic, this implies a lower unemployment of only 8.0\%. In fact, this is close to the actual figure of 7.5\% over the period 1995-1999. The implications for Hungary remain as before: implied unemployment is high. As explained before, this probably partly reflects the actual situation on the labour market. Reducing the tax wedge and the replacement rate, and re-evaluating the recent minimum wage increase, would probably be important steps toward a better functioning labour market in Hungary. The implied unemployment for Poland approaches actual unemployment in the period 1995-1999 quite closely. For the Slovak Republic it is still well below actual unemployment, although in comparison with the second regression it has increased considerably. It is clear however that labour market institutions alone are not capable of explaining unemployment rates in the new member states.

The conclusion that labour market institutions are not the major determinant of unemployment in the new member states is further reinforced by looking at the recent development of the labour market in these countries. Whereas labour market institutions have hardly changed during the last 5 years, unemployment rates have increased considerably in both Poland and the Slovak Republic. As the last column of Table 5 shows, unemployment rates were well above $15 \%$ in both countries in 2005 . Labour market institutions fail to explain this enormous increase. Clearly, other factors are more important in explaining unemployment in the Slovak Republic and Poland. In the concluding chapter some of these factors will be discussed.

\section{Conclusions and discussion}

The enlargement of the European Union with ten new member states presents a major change. Some 20 years ago, most of the new member states were still led by a Communist government. Workers enjoyed a high degree of employment protection 
and pay systems were fairly rigid. Many people in the EU-15 therefore worried about the possible consequences of the new situation. Were labour markets in the EU-15 often blamed for their inflexibility acting as an impediment to economic development, the rigid systems in the former Communist countries would certainly be no better, so the story went. High unemployment in Poland supports this idea. The envisaged rigidity of the Central- and East-European labour markets therefore seems to justify fears for labour market problems in the enlarged European Union.

However, much has happened in the new member states in the past two decades. Since the beginning of the transition, the social security system has been revised drastically: replacement rates are now comparable to those within the EU-15, but benefit duration is markedly shorter in new member states. Employment protection was liberalised and minimum wages were introduced. The collective agreements, as bargained over at the decentralised industry or firm level, now cover the majority of employees in the new member states. In short, labour market institutions in the new member states do on average not differ that much anymore from the institutions in the old member states. If anything, they should be considered more flexible.

Common knowledge suggests that unemployment in the new member states is much higher than in the EU-15. However, in about half of the ten new member states the unemployment rate is actually below the EU-15 average. The main worry with respect to labour market performance is presented by Poland and the Slovak Republic, representing more than half of the population in the new member states. Unemployment rates have dramatically risen in these two countries in recent years, reaching levels of almost 20\%. Our research clearly shows that labour market institutions are not capable of explaining the high level of unemployment, let alone the development. Other factors must be behind these high unemployment rates.

An important factor relates to the transition process the Central and East European countries had to go through. Enterprises had to eliminate labour hoarding in order to become competitive. Many believed that the resulting unemployment would have a transient character. However, restructuring of an economy implies shifting of employees between sectors. The sectoral structure played a critical role. The informal sector is quite important in a number of new member states. Agriculture in Poland is for instance to some extent a refuge sector: poor job opportunities and low unemployment benefits trigger people to make a living cultivating kitchen gardens or small family holdings. One further additional explanation refers to foreign direct investment (FDI). Hungary and the Czech Republic received more than twice the per capita amount Poland and the Slovak Republic received. The amount of FDI a country attracts is influenced by its political and economic stability (Nesporova 2002). Both Poland and the Slovak Republic score low in this respect.

These factors may explain part of the weak labour market performance in Poland and the Slovak Republic, but they cannot possibly explain the strong rise in unemployment since 1998. Part of the explanation is the unfavourable demographic development in both countries. During 1998-2000, the Polish labour force increased significantly due to large groups of young school-leavers entering the labour market. As a result youth unemployment rose significantly in Poland and the Slovak Republic (OECD 2001). 
The most important factor in explaining recent unemployment growth in both countries is however postponed structural reforms. Both countries went through key liberalisation reforms in recent years, while tightening monetary policy at the same time. This has put an upward pressure on unemployment. Furthermore, high job insecurity perceived by workers in these countries impedes relocation of labour from low to high productive sectors.

Do labour market institutions cause high unemployment in the new member states? Our answer is no. The new member states with the highest unemployment rates do not feature overly rigid labour markets. The reasons behind their malfunctioning labour markets are related to other factors. Labour market institutions in the new member states are comparable to those in the EU-15 and can only account for a small part of the problems in Poland and the Slovak Republic. Just as in the EU-15, labour market reforms may be needed in a number of new EU member states in order to further improve economic performance. It would however be wrong to advocate improving the flexibility of the labour market regardless of the specific needs of the country in question. The appropriate policy measures should carefully take into account all the country specific factors and may well be fundamentally different from the actions that are usually suggested to the 15 old member states of the European Union.

\section{Data Appendix}

The regressions in chapter 5 use data for a sample of 21 countries over the period 1960-1999.

This appendix describes the data and the sources from which they were obtained in more detail.

\section{Countries}

We include 21 countries in our regressions. These are the four largest new member states (Poland, the Czech Republic, Hungary and the Slovak Republic) and the 17 countries (Australia, Austria, Belgium, Canada, Denmark, Finland, France, Germany, Ireland, Italy, Japan, the Netherlands, Norway, Sweden, Switzerland, United Kingdom and United States of America) that Belot and Van Ours (2004) include in their regressions. Henceforth we will refer to Belot and Van Ours (2004) as $\mathrm{BvO}$.

\section{Unemployment rate}

The unemployment rate is taken from the OECD for the years 1960-2000. We use the standardised unemployment rate as obtained from the Main Economic Indicators (MEI). 
Tax wedge

For 1960-1979 we rely on the tax rate series constructed by BvO. This tax rate is calculated as the sum of the employment tax rate and the direct tax rate. A more detailed description of their calculations can be found in the data appendix accompanying their publication. Because we were unable to extend this series to the new member states, we decided to use a different indicator for the period 19792000. For this period we use the tax wedge as obtained from the OECD. The series we use refers to a single average production worker and can be found in Table 3/6 in the annex to the OECD-publication 'Taxing Wages 2000-2001'. The total tax wedge is defined there as 'Employees' and employers' social security contributions and personal income tax less transfer payments as percentage of gross labour costs'.

Replacement rate first year

The OECD has collected systematic data on the unemployment benefit replacement ratio for three different family types (single, with dependent spouse, with spouse at work) in three different duration categories (1st year, 2nd and 3rd years, 4th and 5th years) from 1961 to 2001 (every other year). From this, we calculated a summary measure for the replacement rate in the first year by taking a simple average over the first year replacement rates for the three family types. The replacement rate used by $\mathrm{BvO}$ is computed by taking the mean for all nine categories.

Unemployment benefit duration

We follow Nickell (2003) in calculating a measure of the unemployment benefit duration. He starts from the OECD data described in the previous paragraph and computes the indicator by normalising the level of benefit in the later years of the spell on the benefit in the first year of the spell. The exact formula reads as follows: [0.6 (2nd and 3rd year replacement ratio) +0.4 (4th and 5th year replacement ratio)] $\div$ (1st year replacement ratio).

\section{Employment protection legislation}

For the 17 countries for which $\mathrm{BvO}$ have data available, we use the index they constructed. This series measures the strictness of employment regulation with respect to open-ended contracts, fixed-term contracts and temporary work agencies. $\mathrm{See} \mathrm{BvO}$ for further details. For the four new member states we use data constructed by Nicoletti et al. (2000). We normalised these to the same range as the series from $\mathrm{BvO}$.

\section{Union density}

We got the union density series from BvO. The original source is the OECD Labour Market Statistics. 


\section{Centralization}

Index (1-3) characterizing the degree of centralization of the bargaining system, with higher numbers indicating more centralization: 1: firm level, 2 : industry level and 3: national level. Source: BvO.

\section{Coordination}

Index (1-3) characterizing the degree of coordination of the bargaining system, with 3 the most coordinated. Source: BvO.

\section{Active labour market policies}

Expenditure on Active Labour Market Policies as a percentage of GDP is obtained from the OECD Labour Market Statistics. Following Nickell et al. (2003), we normalised the series by dividing it by the unemployment rate.

Statutory minimum wage (as percentage of the average wage)

Source: OECD Labour Market Statistics.

Change in inflation

To measure the change in inflation we start from the consumer price index (CPI) as obtained from the series 'CPI all items' from the OECD. This is an index series, with the value for 1995 normalised at 100. For the four new member states this series is available from 1995 at the latest. For the other 17 countries, this series is available from 1960, with the exception of Denmark, for which the series start at 1968. For Denmark we therefore use a different series, the consumer price index from the Luxembourg Income Studies, for the first two 5-year periods. We obtained this series from $\mathrm{BvO}$, who use it for all countries for the whole sample period.

Inflation in year $t$ is calculated as: $\mathrm{INF}_{t}=\left(\mathrm{CPI}_{t}-\mathrm{CPI}_{t-1}\right) / \mathrm{CPI}_{t-1}$.

Finally, the change in inflation in year $t$ is defined as: $\mathrm{CHI}_{t}=\mathrm{INF}_{t}-\mathrm{INF}_{t-1}$.

\section{References}

Belot M, Van Ours J (2004) Does the recent success of some OECD countries in lowering their unemployment rates lie in the clever design of their labour market reforms? Oxford Econ Papers 56:621-642

Blanchard O, Wolfers J (2000) The role of shocks and institutions in the rise of European unemployment: the aggregate evidence. Econ J (Conference Papers) 110:C1-C33

Boeri T (2002) Social Policy: one for all?, Paper presented at the CPB-ENEPRI conference 'Policy competition and the welfare state', November 30, 2002, The Hague

Cazes S (2002) Do labour market institutions matter in transition economies? An analysis of labour market flexibility in the late nineties. International Labour Organization, Geneva

Dolado J, Kramarz F, Machin S, Manning A, Margolis D, Teulings C (1996) The economic impact of minimum wages in Europe. Econ Policy 23:319-370 
European Commission (2003) Employment in Europe. Recent trends and prospects. Directorate-General for Employment and Social Affairs. Brussels

European Commission (2004) Commission recommendation on the 2004 update of the broad guidelines of the economic policies of the member states and the community (for the 2003-2005 period), Brussels

IMF (2003) Unemployment and labor market institutions: Why reforms pay off. In: World Economic Outlook, April 2003, 129-150

Mortensen D, Pissarides C (1999) New developments in models of search in the labor market. In: Ashenfelter O, Card D (eds) Handbook of labor economics. Amsterdam, North-Holland, 2567-2627

Nesporova A. (2002) Why unemployment remains so high in Central and Eastern Europe. International Labour Organization, Employment and Labour Market Policies Branch, Geneva

Nesporova A, Cazes S (2003) Employment protection legislation (EPL) and its effects on labour market performance, high-level tripartite conference on social dialogue, Malta, Valetta, 28 February-1 March 2003. International Labour Organisation, Employment and Labour Market Policies Branch, Geneva

Nickell SJ, Nunziata L, Ochel W, Quintini G (2003) The beveridge curve, unemployment and wages in the OECD from the 1960s to the 1990s. In: Aghion P, Frydman R, Stiglitz J, Woodford M (eds) Knowledge, information, and expectations in modern macroeconomics. Essays in Honor of E. S. Phelps, Princeton University Press, Princeton

Nickell S, Nunziata L, Ochel W (2005) Unemployment in the OECD since the 1960s. what do we know? Econ J 115:1-27

Nicoletti G, Scarpetta S, Boylaud O (2000) Summary indicators of product market regulation with an extension to employment protection legislation. OECD Economics Department Working Papers no. 226

OECD (1994) The OECD Jobs Study. Paris

OECD (1997) Employment outlook, chapter 3: economic performance and the structure of collective bargaining, Paris

OECD (1999) Employment Outlook, Paris

OECD (2001) Economic survey Poland 2000-2001. Paris

OECD (2004) Benefits and wages, OECD Indicators, Paris

Riboud M, Sánchez-Páramo C, Silva-Jáuregui C (2002) Does Eurosclerosis matter? Institutional reform and labor market performance in central and eastern European countries in the 1990s. The World Bank, social protection unit, human development network, social protection discussion paper series 0202

Scarpetta S, Reutersward A (1994) Unemployment benefit systems and active labour market policies in central and eastern Europe: an overview. In: OECD (ed) Unemployment in transition countries: transient or Persistent? Paris

Soskice D (1990) Wage determination: the changing role of institutions in advanced industrialized countries. Oxford Rev Econ Policy 6(4):36-61

World Bank (2002) Labour policy dilemmas preceding EU enlargement, labour markets of the accession countries: fit to join? In Transition Newsletter, July-August-September 2002 